\title{
Lithium Carbonate Therapy Causes Nephrotoxicity and its Alleviation with Ascorbic Acid in Wistar Albino Rats
}

\section{Modawe GA ${ }^{1 *}$ and ElBagir NM²}

1Biochemistry Department, Omdurman Islamic University, Sudan

2Biochemistry Department, Faculty of Veterinary Medicine, University of Khartoum, Sudan

*Corresponding author: Gad Allah Modawe, Biochemistry department, Faculty of Medicine, Omdurman Islaimc university, Omdurman, Sudan, Tel: 00249912894911; Email: gadobio77@hotmail.com

\section{Research article}

Volume 3 Issue 3

Received Date: May 09, 2018

Published Date: May 31, 2018

\section{Abstract}

Backgrounds: Lithium carbonate is drug has been used for prolonged treatment of psychiatric disorders. But was known to be accompanied by side effects and highly toxicity especially to renal tissue.

Objectives: this study aimed to investigate the influence of lithium carbonate and ascorbic acid on the kidney tissue in Wistar albino rats.

Methodology: Ninety rats were used in two experiments. The experiment was performed in three months and blood samples were collected monthly, then specimen of the kidney, was used for histopathological examination. In experiment 1 , forty rats were used and divided to four groups, three groups were subjected to different oral doses of drug $(9,17$ and $34 \mathrm{mg} / \mathrm{kg} / \mathrm{BW}$ ) daily and the fourth was kept as control group. In experiment 2, fifty rats were used and divided to five groups, ascorbic acid, $(7 \mathrm{mg} / \mathrm{kg} \mathrm{BW})$ as antioxidant was added to the different doses of drug during the experimental period.

Results: Urea and creatinine showed significantly $(\mathrm{P} \leq 0.005)$ higher levels in the groups used different doses of the lithium therapy compared to the control group. Only the uric acid showed significantly ( $\mathrm{P} \leq 0.003$ ) lower level compared to the control group. Tubular necrosis, congestion and infiltration of inflammatory cells were the common pathological lesions observed in the kidney and congestion of capillaries was the common pathological lesion at different doses of lithium carbonate. The serum levels of urea and uric acid were significantly $(p \leq 0.004)$ increased in all groups of the treated rats compared to the control group. The serum creatinine was significantly $(\mathrm{P} \leq 0.000)$ higher in rats treated with $9 \mathrm{mg} / \mathrm{kg}$ BW, and ascorbic acid but other groups treated with higher doses and ascorbic acid showed significantly $(\mathrm{p} \leq 0.000)$ lower levels compared to the control group. For histopatholgical changes, when drug was accompanied by Lascorbic acid, the infiltration of inflammatory cells was less in kidney compared to the groups treated with lithium carbonate alone. 


\section{International Journal of Biochemistry \& Physiology}

Conclusions: The use of L-ascorbic acid alone also reduced infiltration of inflammatory cells. The study recommended that patients on drug should be periodically evaluated for renal dysfunction and also advised to be supplied with ascorbic acid, to reduce the toxicity of lithium therapy. Future studies should investigate the effect of different doses of the ascorbic acid on responses to lithium therapy. Also the effects of other antioxidants on drug responses should be tested.

Keywords: Nephrotoxicity; Nephritis; Lithium carbonate; Ascorbic acid; Albino rats

\section{Introduction}

Lithium is the lightest alkali metal used effectively to treat manic disorders and in preventing recurring manic depressive episodes [1,2] since it has a narrow therapeutic range which makes blood serum lithium levels monitoring mandatory to avoid lithium intoxication [3]. Chronic lithium treatment can produce significant changes in different organs like kidney, liver, brain and spleen [4]. Also Lithium salts cause ocular side effects [5], polyuria and polydipsia, and impaired renal concentration capacity after water deprivation [6]. Lithium is well absorbed by the stomach and doudeneum with no absorption in the large intestine, after ingestion peak serum lithium levels are seen after two and a half hour and completed within 6-8 hours [7]. Lithium does not bind to plasma protein but binds to some legend [8], as it moves slowly from extra- cellular compartment to intracellular space it may require 6-10 days to reach steady blood concentration and the desired therapeutic responses [1,9]. Lithium effects have been investigated in details in the brain, intestine, liver and thyroid gland, and revealed many deformities and histological alteration $[10,11]$. Antioxidant supplements may include a number of different free radical-fighting compounds. It is thought that antioxidants, such as vitamin C, E and beta carotene, may reduce the damage caused by free radical in the bodies by inhibiting their formation [12]. The objective of this study was to assess the nephrotoxicity by measure serum creatinine, urea and uric acid and histopathological of kidney tissue, of drug and to compare it with its use, accompanied by ascorbic acid as an antioxidant, in Wistar Albino rats.

\section{Material and Methods}

\section{Animals}

This research was carried on 90 adult male rats obtained from the Faculty of Pharmacy, University of Khartoum, Sudan, reared in the premises of the Department of Biochemistry, Faculty of Veterinary
Medicine, University of Khartoum. All animals were maintained on standard rat diet and water and used for two experiments.

\section{Chemicals}

Lithium preparation used in this study is $\mathrm{Li}_{2} \mathrm{Co}_{3}$. (ElNile Company, Egypt with the trade name Prianil CR) presented in the form of tablets of $400 \mathrm{mg}$. The dose of the drug was calculated by converting adult human therapeutic dose (600-2400 $\mathrm{mg} /$ day) to animal dose $[13,14]$.

L-ascorbic acid made in the European Union (Scharlauchemie S.A) in the form of powder. Each of the $\mathrm{Li}_{2} \mathrm{Co}_{3}$ and the ascorbic acid were dissolved in distilled water before use and the calculated doses were given orally using stomach tubes.

\section{Experiment I (The Effect of Adding Different Doses of Lithium Carbonate in Wistar Albino Rats)}

Forty male adult rats weighed between $(125-217 \mathrm{~g})$. Food and water provided ad libitum for two weeks, before experiment, as adaptation periods, were allotted random to four groups, each of 10 rats; group 1, were to be fed the basal rat diet and water, served as control group. Groups $(2,3$, and 4$)$ received the diet and water and treated by lithium carbonate $\left(\mathrm{Li}_{2} \mathrm{Co}_{3}\right)$ at doses of $9 \mathrm{mg} / \mathrm{kg} \mathrm{BW}$, $17 \mathrm{mg} / \mathrm{kg}$ BW $34 \mathrm{mg} / \mathrm{kg}$ BW respectively. The $\mathrm{Li}_{2} \mathrm{Co}_{3}$ was dissolved in distilled water and the calculated doses were given orally using stomach tubes. The duration of experiment is three months. After two weeks of adaptation period. Blood was collected and body weights of animals were measured at the zero time, after 1 month, 2 month and at the end of the experiment. The animals were anaesthetized with diethyl ether and sacrificed at end of the experiment. Tissues from the kidney were removed and specimens were fixed in 10\% neutral buffered formalin for histopathology. 


\section{International Journal of Biochemistry \& Physiology}

\section{Experiment II (The Effect of Adding Different Doses of Lithium Carbonate Pluse L- Ascorbic Acid in Wister Albino Rats)}

Fifty male adult rats weighted between (100-200g) were used in this experiment. Food and water provided ad libitum for two weeks before the start of the experiment as adaptation period.

The rats were allotted at random to five groups, each of 10 rats;

Group 1 continued to be fed the basal rat diet and water, and served as control group (negative control). Group 2 (positive control) received ascorbic acid $(7 \mathrm{mg} / \mathrm{kg} \mathrm{BW}$ ). Group 3 received lithium carbonate and ascorbic acid ( 9 $\mathrm{mg} / \mathrm{kg} \mathrm{BW} \mathrm{li}_{2} \mathrm{Co}_{3}+7 \mathrm{mg} / \mathrm{kg} \mathrm{BW}$ ascorbic acid).

Group 4 received lithium carbonate and ascorbic acid $\left(17 \mathrm{mg} / \mathrm{kg} \mathrm{BW} \mathrm{li}_{2} \mathrm{Co}_{3}+7 \mathrm{mg} / \mathrm{kg} \mathrm{BW}\right.$ ascorbic acid).

Group 5 received lithium carbonate and ascorbic acid (34mg/kg BW li ${ }_{2} \mathrm{Co}_{3}+7 \mathrm{mg} / \mathrm{kg} \mathrm{BW}$ ascorbic acid).

The $\mathrm{Li}_{2} \mathrm{Co}_{3}$ and ascorbic acid were dissolved in distilled water and the calculated doses were given orally using stomach tube. The duration of this experiment was three months. After two weeks of the adaptation period the blood sample were collected of animals was recorded at zero time, then blood was collected monthly to assay biochemical parameters, after one month, two month and at the end of the experiment.

The animals were anaesthetized with diethyl ether and sacrificed at end of the experiment. Tissue from the kidney specimens were removed and were fixed in $10 \%$ neutral buffered formalin for histopathology.

The blood samples were allowed to clot, and the sera were separated by centrifugation at $3000 \mathrm{rpm}$ for $5 \mathrm{~min}$ and stored at $-20^{\circ} \mathrm{C}$ until the analysis was performed. The estimation of serum chemistry was performed using spectro-photometric methods and commercial kits. The parameters determined were urea, creatinine and uric acid.

\section{Histological Investigations}

The method described by Turner RD, et al. was used for histological investigations [15]. Tissue specimens were obtained from the kidney of rats for histological examination. After sacrificing the rats the specimens were immediately preserved in $10 \%$ formalin. The specimens were then processed in paraffin using an automatic tissue processor (Elliot tissue processor, London). The specimens were then cut to sections, and stained with haematoxylin and eosin.

\section{Statistical Analysis}

Mean values in body weight, blood and antioxidant data were expressed as (Mean \pm SE) and statistical analysis was carried using computerized SPSS program version (21) with one way ANOVA. One-way Analysis of Variance (ANOVA) was used for determining the significance [16]. One-way analysis of variance (ANOVA) assessed for biochemical parameters; and then means were separated using DMRT. The animal experiments were designed by the complete randomized design (CRD); factorial arrangement $4 \times 4$. Where 4 indicate four groups (A; control, B, C and D; treated) and the other 4 indicate times $(0,1,2,3$ months $)$ for experiment one, and also factorial arrangement $4 \times 5$. Where 4 indicate five groups (A; control, B, C, D and E; treated) and the other 4 indicate times $(0,1,2,3$ months)for experiment two.

RCD $\equiv$ Randomized Complete Design

ANOVA $\equiv$ Analysis of variance

DMRT $\equiv$ Duncan multiple range test.

\section{Results}

\section{Biochemical Parameters of the Kidney}

In the experiment I: The effect of adding different doses of lithium carbonate on urea in wistar albino rats is presented in table 1 . The mean of serum urea showed highly significantly $(\mathrm{p}=0.002)$ increase in all treated groups of rats after one month of the experiment, but after second month the group D was significantly $(\mathrm{p}=0.027)$ decreased and also group $\mathrm{C}$ was slightly decreased but group B was significantly $(p=0.027)$ increased compared to the control group. At the end of the experimental period the concentration serum urea was insignificantly higher in group B also groups C and D were slightly insignificantly decreased compared to the control group. The effect of adding different doses of lithium carbonate on creatinine in wistar albino rats is presented in table 2. The mean of serum creatinine showed significant $(p=0.003)$ increase in group $B$ compared to its starting values, also groups $C$ and $D$ were significant $(p=0.003)$ increased after one month of the experiment. After the second month group $\mathrm{B}$ was significantly $(\mathrm{p}=0.024)$ higher than the control group, and also groups $\mathrm{C}$ and $\mathrm{D}$ showed insignificantly higher values compared to the control group. At the end of the experimental period the concentration of the serum creatinine was still significantly $(\mathrm{p}=0.000)$ higher in group $\mathrm{B}$ than its starting value, but groups $\mathrm{C}$ and $\mathrm{D}$ re turned to their starting levels, similar to the control group. The 


\section{International Journal of Biochemistry \& Physiology}

effect of adding different doses of lithium carbonate on serum uric acid in Wistar albino rats is presented in table 3. The mean of serum uric acid showed significant $(p=0.103)$ lower levels in groups $C$ and $D$ and insignificant in group B after one month of the experiment compared to the control group. After the second month the serum uric acid was still lower in all groups of the treated rats compared to the control group. At the end of the experimental period the concentration of the serum uric acid was significantly $(p=0.022)$ higher in all groups of the treated rats compared to the control group.

Also in experiment II: The effect of adding different doses of lithium carbonate and L-ascorbic acid on urea in Wistar albino rats is presented in table 4 . The mean of serum urea showed lower levels in all treated groups after one month of the experiment except group D which showed similar level compared to the control group. After the second month all treated groups showed more or less similar levels compared to the control group with slightly lower values in groups D and E. At the end of the experiment period the concentration of serum urea was higher in the treated groups, with high significance $(\mathrm{P}=0.014)$ in group $\mathrm{C}$ compared to the control group and group B. The effect of adding different doses of lithium carbonate and L-ascorbic acid on creatinine in Wistar albino rats is presented in table 5 . The mean of serum creatinine showed slightly insignificantly higher level in the group C, but groups B, D and E were not affected after one month of the experiment compared to the control group. After second the month the serum creatinine was significantly $(p=0.005)$ lower in the treated groups compared to the control group. At the end of the experimental period the concentration of serum creatinine was significantly $(\mathrm{P}=0.001)$ higher in group $\mathrm{C}$ compared to all other groups. Also all groups showed significantly $(p=0.000)$ lower levels compared to the time zero except group $\mathrm{C}$. The effect of adding different doses of lithium carbonate and L-ascorbic acid on uric acid in wistar albino rats is presented in table 6 . The mean value of serum uric acid showed significant $(\mathrm{p}=0.000)$ increase in all groups of rats after one the month of the experiment compared to time zero. This elevation continued after the second month for the serum uric acid except group C which returned to a level similar time zero. At the end of the experimental period the concentration of serum uric acid was significantly $(p=0.026)$ higher in groups $D$ and $E$, compared to the control group. The effects of different doses of lithium carbonate alone or with L- ascorbic acid on serum urea is presented in figure 1 . The effects of different doses of lithium carbonate alone or with Lascorbic acid on serum creatinine is presented in figure 2 . The effects of different doses of lithium carbonate alone or with L- ascorbic acid on serum uric acid is presented in figure 3.

\section{Histopathological Findings of the Kidney}

In the kidney figure 5-7 tubular necrosis, congestion and infiltration of inflammatory cells were the common pathological lesions observed in the kidney at different doses of lithium carbonate in the first experiment. The protective effect of L-ascorbic acid on kidney tubules was (suitable) with lithium carbonate doses, Figures 9-11 Lascorbic acid reduced infiltration of inflammatory cells.

\begin{tabular}{|c|c|c|c|c|c|c|}
\hline \multirow{2}{*}{ Treatment } & \multicolumn{4}{|c|}{ Months } & \multirow{2}{*}{ Overall } & \multirow{2}{*}{ P-value. } \\
\hline & Zero & $1^{\text {st }}$ & $2^{\text {nd }}$ & $3^{\text {rd }}$ & & \\
\hline $\mathbf{A}$ & $42.69 \pm 2.58^{\mathrm{BCD}}$ & $52.33 \pm 2.02^{\mathrm{bcd} A C}$ & $63.34 \pm 2.99 \mathrm{dAB}$ & $59.07 \pm 2.37^{\mathrm{A}}$ & $54.35 \pm 1.74 \mathrm{~B}$ & $0.000^{* *}$ \\
\hline B & $45.09 \pm 1.09 \mathrm{BCD}$ & $66.95 \pm 3.42^{\mathrm{aA}}$ & $67.56 \pm 5.71^{\mathrm{dA}}$ & $62.15 \pm 6.52^{\mathrm{A}}$ & $60.29 \pm 2.63^{\mathrm{AC}}$ & $0.002^{* *}$ \\
\hline $\mathrm{C}$ & $47.19 \pm 1.87 \mathrm{BC}$ & $66.77 \pm 2.98^{\mathrm{aAD}}$ & $57.81 \pm 4.84^{\mathrm{A}}$ & $55.63 \pm 2.58^{\mathrm{B}}$ & $56.85 \pm 1.92^{\text {B }}$ & $0.002^{* *}$ \\
\hline D & $46.41 \pm 0.94 \mathrm{BD}$ & $72.76 \pm 6.01^{\mathrm{aACD}}$ & $46.87 \pm 2.59$ abBD & $58.39 \pm 4.42^{\mathrm{ABC}}$ & $55.27 \pm 2.55^{\text {в }}$ & $0.000^{* *}$ \\
\hline Overall & $45.35 \pm 0.88^{\mathrm{B}}$ & $64.05 \pm 2.08^{\mathrm{A}}$ & $59.87 \pm 2.46^{\mathrm{AB}}$ & $58.55 \pm 1.87 \mathrm{AB}$ & & \\
\hline P-value. & $0.297 \mathrm{Ns}$ & $0.002^{* *}$ & $0.027^{*}$ & $0.710^{\mathrm{Ns}}$ & & \\
\hline
\end{tabular}

Table 1: The effect of adding different doses $(\mathrm{mg} / \mathrm{kg})$ levels of lithium carbonate on serum urea $(\mathrm{mg} / \mathrm{dL})$ in Wistar albino rats.

Key:

A $\equiv$ Control group

$\mathrm{B} \equiv$ Treated with $9 \mathrm{mg} / \mathrm{kg} / \mathrm{BW}$ lithium carbonate

$\mathrm{C} \equiv$ Treated with $17 \mathrm{mg} / \mathrm{kg} / \mathrm{BW}$ lithium carbonate

$\mathrm{D} \equiv$ Treated with $34 \mathrm{mg} / \mathrm{kg} / \mathrm{BW}$ lithium carbonate. 


\section{International Journal of Biochemistry \& Physiology}

\begin{tabular}{|c|c|c|c|c|c|c|}
\hline \multirow{2}{*}{ Treatment } & \multicolumn{4}{|c|}{ Months } & \multirow{2}{*}{ Overall } & \multirow{2}{*}{ P-value. } \\
\hline & Zero & $1^{\text {st }}$ & $2^{\text {nd }}$ & $3^{\text {rd }}$ & & \\
\hline $\mathbf{A}$ & $0.48 \pm 0.05^{\mathrm{BC}}$ & $0.98 \pm 0.02^{\mathrm{dACD}}$ & $0.63 \pm 0.06^{\mathrm{bAB}}$ & $0.55 \pm 0.05^{\mathrm{B}}$ & $0.66 \pm 0.04^{\mathrm{B}}$ & $0.000^{* *}$ \\
\hline B & $0.45 \pm 0.03^{\mathrm{BCD}}$ & $0.99 \pm 0.04 \mathrm{dADA}$ & $0.89 \pm 0.03^{\mathrm{aAD}}$ & $0.62 \pm 0.05^{\mathrm{ABC}}$ & $0.75 \pm 0.05^{\mathrm{AC}}$ & $0.000^{* *}$ \\
\hline C & $0.51 \pm 0.01^{\mathrm{BC}}$ & $0.87 \pm 0.05^{\text {bcAD }}$ & $0.77 \pm 0.05^{\mathrm{AD}}$ & $0.51 \pm 0.05^{\mathrm{BC}}$ & $0.67 \pm 0.03^{\mathrm{BD}}$ & $0.000^{* *}$ \\
\hline D & $0.50 \pm 0.05^{\mathrm{BC}}$ & $0.76 \pm 0.05^{\mathrm{abAD}}$ & $0.74 \pm 0.10^{\mathrm{AD}}$ & $0.49 \pm 0.04 \mathrm{BC}$ & $0.61 \pm 0.04 \mathrm{BC}$ & $0.005^{* *}$ \\
\hline Overall & $0.486 \pm 0.019 \mathrm{BC}$ & $0.911 \pm 0.024^{\mathrm{A}}$ & $0.761 \pm 0.032^{\mathrm{AB}}$ & $0.538 \pm 0.024^{\mathrm{B}}$ & & \\
\hline P-value. & $0.716^{\mathrm{Ns}}$ & $0.003^{*}$ & $0.024^{*}$ & $0.383^{\mathrm{Ns}}$ & & \\
\hline
\end{tabular}

Table 2: Effect of adding different doses $(\mathrm{mg} / \mathrm{kg})$ of lithium carbonate on serum creatinine $(\mathrm{mg} / \mathrm{dL})$ in Wistar albino rats.

\begin{tabular}{|c|c|c|c|c|c|c|}
\hline \multirow{2}{*}{ Treatment } & \multicolumn{4}{|c|}{ Months } & \multirow{2}{*}{ Overall } & \multirow{2}{*}{ P-value. } \\
\hline & Zero & $1^{\text {st }}$ & $2^{\text {nd }}$ & $3^{\text {rd }}$ & & \\
\hline $\mathbf{A}$ & $5.56 \pm 0.55^{\mathrm{dBD}}$ & $8.80 \pm 0.96^{\mathrm{cdACD}}$ & $4.15 \pm 0.50^{\mathrm{B}}$ & $3.08 \pm 0.36^{\mathrm{bcdAB}}$ & $5.39 \pm 0.46^{\mathrm{D}}$ & $0.000^{* *}$ \\
\hline B & $5.25 \pm 0.45^{\mathrm{dB}}$ & $6.89 \pm 0.69 \mathrm{ACC}$ & $4.05 \pm 0.29 \mathrm{~B}$ & $4.69 \pm 0.60^{\mathrm{aB}}$ & $5.26 \pm 0.31^{\mathrm{D}}$ & $0.003^{* *}$ \\
\hline $\mathrm{C}$ & $4.36 \pm 0.32^{\mathrm{B}}$ & $6.79 \pm 0.48^{\mathrm{aACD}}$ & $3.81 \pm 0.51^{\mathrm{B}}$ & $4.12 \pm 0.22^{\mathrm{aB}}$ & $4.77 \pm 0.27^{\mathrm{D}}$ & $0.000^{* *}$ \\
\hline D & $2.85 \pm 0.42^{\mathrm{abcdBD}}$ & $6.40 \pm 0.57 \mathrm{aACD}$ & $3.37 \pm 0.45^{\text {в }}$ & $4.24 \pm 0.18^{\mathrm{aAB}}$ & $4.08 \pm 0.32^{\mathrm{ABC}}$ & $0.000^{* *}$ \\
\hline Overall & $4.50 \pm 0.27^{\mathrm{B}}$ & $7.29 \pm 0.38^{\mathrm{A}}$ & $3.88 \pm 0.22^{\mathrm{AB}}$ & $3.96 \pm 0.20^{\mathrm{AB}}$ & & \\
\hline P-value. & $0.000^{* *}$ & $0.103^{\mathrm{Ns}}$ & $0.680^{\mathrm{Ns}}$ & $0.022^{*}$ & & \\
\hline
\end{tabular}

Table 3: Effect of adding different doses $(\mathrm{mg} / \mathrm{kg})$ of lithium carbonate on serum uric acid $(\mathrm{mg} / \mathrm{dL})$ in Wistar albino rats.

\begin{tabular}{|c|c|c|c|c|c|c|}
\hline \multirow{2}{*}{ Treatment } & \multicolumn{4}{|c|}{ Months } & \multirow{2}{*}{ Overall } & \multirow{2}{*}{ P-value. } \\
\hline & Zero & $1^{\text {st }}$ & $2^{\text {nd }}$ & $3^{\text {rd }}$ & & \\
\hline $\mathbf{A}$ & $44.21 \pm 4.3^{\mathrm{C}}$ & $49.34 \pm 2.9^{\mathrm{D}}$ & $56.57 \pm 4.4^{\mathrm{AD}}$ & $34.64 \pm 1.7^{\mathrm{BC}}$ & $46.20 \pm 2.3^{\mathrm{C}}$ & $0.002^{* *}$ \\
\hline B & $47.34 \pm 3.1^{\mathrm{CD}}$ & $45.09 \pm 1.2^{\mathrm{CD}}$ & $56.05 \pm 2.1 \mathrm{ABD}$ & $34.16 \pm 3.0^{\mathrm{ABC}}$ & $45.70 \pm 1.9^{\mathrm{C}}$ & $0.000^{* *}$ \\
\hline $\mathrm{C}$ & $43.21 \pm 3.6$ & $47.03 \pm 2.1$ & $56.72 \pm 2.4$ & $58.10 \pm 9.2^{\mathrm{ab}}$ & $51.3 \pm 2.7 \mathrm{~A}^{\mathrm{BCD}}$ & $0.145^{\mathrm{Ns}}$ \\
\hline D & $42.50 \pm 3.8$ & $49.67 \pm 4.3$ & $50.80 \pm 4.9$ & $45.20 \pm 5.9$ & $47.00 \pm 2.4^{\mathrm{C}}$ & $0.598^{\mathrm{Ns}}$ \\
\hline $\mathbf{E}$ & $47.96 \pm 3.8$ & $43.16 \pm 1.2$ & $50.66 \pm 5.2$ & $49.28 \pm 2.4$ & $47.80 \pm 2.5^{\mathrm{C}}$ & $0.469^{\mathrm{Ns}}$ \\
\hline Overall & $45.05 \pm 1.6^{\mathrm{C}}$ & $46.86 \pm 1.1^{\mathrm{C}}$ & $54.16 \pm 1.8^{\mathrm{ABC}}$ & $44.28 \pm 2.7^{\mathrm{C}}$ & & \\
\hline P-value. & $0.787^{\mathrm{Ns}}$ & $0.369^{\mathrm{Ns}}$ & $0.661^{\mathrm{Ns}}$ & $0.014^{*}$ & & \\
\hline
\end{tabular}

Table 4: Effect of adding different doses (mg/kg) of Li2Co3 and L -ascorbic acid on serum urea (mg/dL) in rats.

Key:

$A \equiv$ Control group (negative control) .

$\mathrm{B} \equiv$ Treated with $7 \mathrm{mg} / \mathrm{kg} / \mathrm{BW} \mathrm{L}$-ascorbic acid (positive control).

$\mathrm{C} \equiv$ Treated with $17 \mathrm{mg} / \mathrm{kg} / \mathrm{BW}$ lithium carbonate and $7 \mathrm{mg} / \mathrm{kg} / \mathrm{BW} \mathrm{L}$-ascorbic acid.

$\mathrm{D} \equiv$ Treated with $34 \mathrm{mg} / \mathrm{kg} / \mathrm{BW}$ lithium carbonate and $7 \mathrm{mg} / \mathrm{kg} / \mathrm{BW}$ L-ascorbic acid

$\mathrm{E} \equiv$ Treated with $34 \mathrm{mg} \mathrm{Li} 2 \mathrm{Co} 3+7 \mathrm{mg} / \mathrm{kg}$ ascorbic acid

\begin{tabular}{|c|c|c|c|c|c|c|}
\hline \multirow{2}{*}{ Treatment } & \multicolumn{4}{|c|}{ Months } & \multirow{2}{*}{ Overall } & \multirow{2}{*}{ P-value. } \\
\cline { 2 - 6 } & Zero & $\mathbf{1}^{\text {st }}$ & $\mathbf{2}^{\text {nd }}$ & 3 $^{\text {rd }}$ & & \\
\hline A & $1.01 \pm 0.01^{\mathrm{bBCD}}$ & $0.69 \pm 0.03^{\mathrm{AC}}$ & $0.88 \pm 0.03^{\mathrm{beABD}}$ & $0.64 \pm 0.03^{\mathrm{cAC}}$ & $0.81 \pm 0.03^{\mathrm{Ns}}$ & $0.000^{* *}$ \\
\hline B & $1.27 \pm 0.08^{\mathrm{adeBCD}}$ & $0.65 \pm 0.07^{\mathrm{A}}$ & $0.67 \pm 0.06^{\mathrm{aA}}$ & $0.63 \pm 0.05^{\mathrm{cA}}$ & $0.80 \pm 0.06^{\mathrm{Ns}}$ & $0.000^{* *}$ \\
\hline C & $1.11 \pm 0.04^{\mathrm{BC}}$ & $0.71 \pm 0.05^{\mathrm{AD}}$ & $0.81 \pm 0.04^{\mathrm{A}}$ & $0.98 \pm 0.09^{\mathrm{abdeB}}$ & $0.90 \pm 0.04^{\mathrm{DE}}$ & $0.000^{* *}$ \\
\hline $\mathbf{D}$ & $0.98 \pm 0.08^{\mathrm{bBCD}}$ & $0.69 \pm 0.03^{\mathrm{A}}$ & $0.79 \pm 0.05^{\mathrm{A}}$ & $0.69 \pm 0.06^{\mathrm{cA}}$ & $0.78 \pm 0.03^{\mathrm{C}}$ & $0.006^{* *}$ \\
\hline E & $0.89 \pm 0.04^{\mathrm{bBCD}}$ & $0.64 \pm 0.05^{\mathrm{A}}$ & $0.66 \pm 0.02^{\mathrm{aA}}$ & $0.63 \pm 0.04^{\mathrm{cA}}$ & $0.71 \pm 0.03^{\mathrm{C}}$ & $0.000^{* *}$ \\
\hline Overall & $1.05 \pm 0.03^{\mathrm{BCD}}$ & $0.68 \pm 0.02^{\mathrm{AC}}$ & $0.76 \pm 0.02^{\mathrm{AB}}$ & $0.71 \pm 0.03^{\mathrm{A}}$ & & \\
\hline $\boldsymbol{P}$-value. & $0.001^{* *}$ & $0.814^{\mathrm{Ns}}$ & $0.005^{* *}$ & $0.001^{*}$ & & \\
\hline
\end{tabular}

Table 5: Effect of adding different doses $(\mathrm{mg} / \mathrm{kg})$ of $\mathrm{Li}_{2} \mathrm{Co}_{3}$ and $\mathrm{L}$-ascorbic acid on serum creatinine $(\mathrm{mg} / \mathrm{dL})$ in rats. 


\section{International Journal of Biochemistry \& Physiology}

\begin{tabular}{|c|c|c|c|c|c|c|}
\hline \multirow{2}{*}{ Treatment } & \multicolumn{4}{|c|}{ Months } & \multirow{2}{*}{ Overall } & \multirow{2}{*}{ P-value. } \\
\hline & Zero & 1st $^{\text {st }}$ & $2^{\text {nd }}$ & $3^{\text {rd }}$ & & \\
\hline A & $1.61 \pm 0.24 \mathrm{eBCD}$ & $4.98 \pm 0.40^{\mathrm{AD}}$ & $4.98 \pm 0.45^{\mathrm{AD}}$ & $2.89 \pm 0.19 \mathrm{ABC}$ & $3.62 \pm 0.32^{\mathrm{Ns}}$ & $0.000^{* *}$ \\
\hline $\mathbf{B}$ & $1.75 \pm 0.10^{\mathrm{eBCD}}$ & $4.20 \pm 0.45^{\mathrm{AD}}$ & $4.38 \pm 0.40^{\mathrm{AD}}$ & $2.71 \pm 0.13^{\mathrm{ABC}}$ & $3.30 \pm 0.26^{\mathrm{E}}$ & $0.000^{* *}$ \\
\hline $\mathrm{C}$ & $2.06 \pm 0.18^{\mathrm{eBC}}$ & $4.49 \pm 0.17^{\mathrm{ACD}}$ & $5.31 \pm 0.47^{\mathrm{ABD}}$ & $2.83 \pm 0.11^{\mathrm{BC}}$ & $3.70 \pm 0.28^{\mathrm{Ns}}$ & $0.000^{* *}$ \\
\hline D & $2.17 \pm 0.22^{\mathrm{eBCD}}$ & $4.88 \pm 0.39 \mathrm{AD}$ & $4.40 \pm 0.55^{\mathrm{A}}$ & $3.54 \pm 0.29 \mathrm{AB}$ & $3.77 \pm 0.27^{\mathrm{Ns}}$ & $0.000^{* *}$ \\
\hline $\mathbf{E}$ & $3.51 \pm 0.34 \mathrm{abcdB}$ & $5.38 \pm 0.38 \mathrm{ACD}$ & $3.88 \pm 0.53^{\mathrm{B}}$ & $3.39 \pm 0.23^{\mathrm{B}}$ & $4.04 \pm 0.24^{\mathrm{B}}$ & $0.004^{* *}$ \\
\hline Overall & $2.22 \pm 0.15^{\text {ВС }}$ & $4.79 \pm 0.17^{\mathrm{A}}$ & $4.59 \pm 0.22^{\mathrm{A}}$ & $3.07 \pm 0.10 \mathrm{~B}^{\mathrm{AC}}$ & & \\
\hline P-value. & $0.000^{* *}$ & $0.221^{\mathrm{Ns}}$ & $0.281^{\mathrm{Ns}}$ & $0.026^{*}$ & & \\
\hline
\end{tabular}

Table 6: Effect of adding different doses $(\mathrm{mg} / \mathrm{kg})$ of $\mathrm{Li}_{2} \mathrm{Co}_{3}$ and $\mathrm{L}$-ascorbic acid on serum uric acid $(\mathrm{mg} / \mathrm{dL})$ in rats.

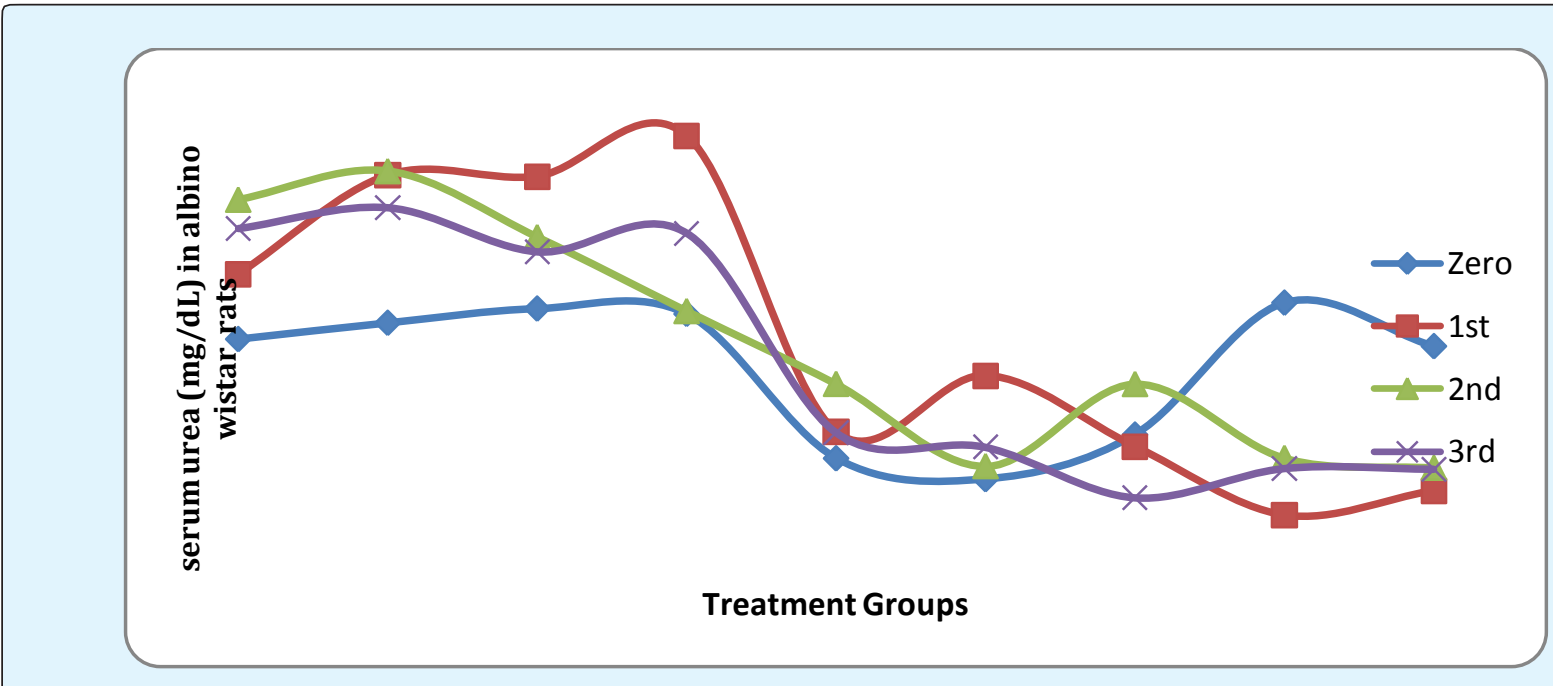

Figure 1: The effects of different doses of lithium carbonate alone or with L- ascorbic acid on serum urea.

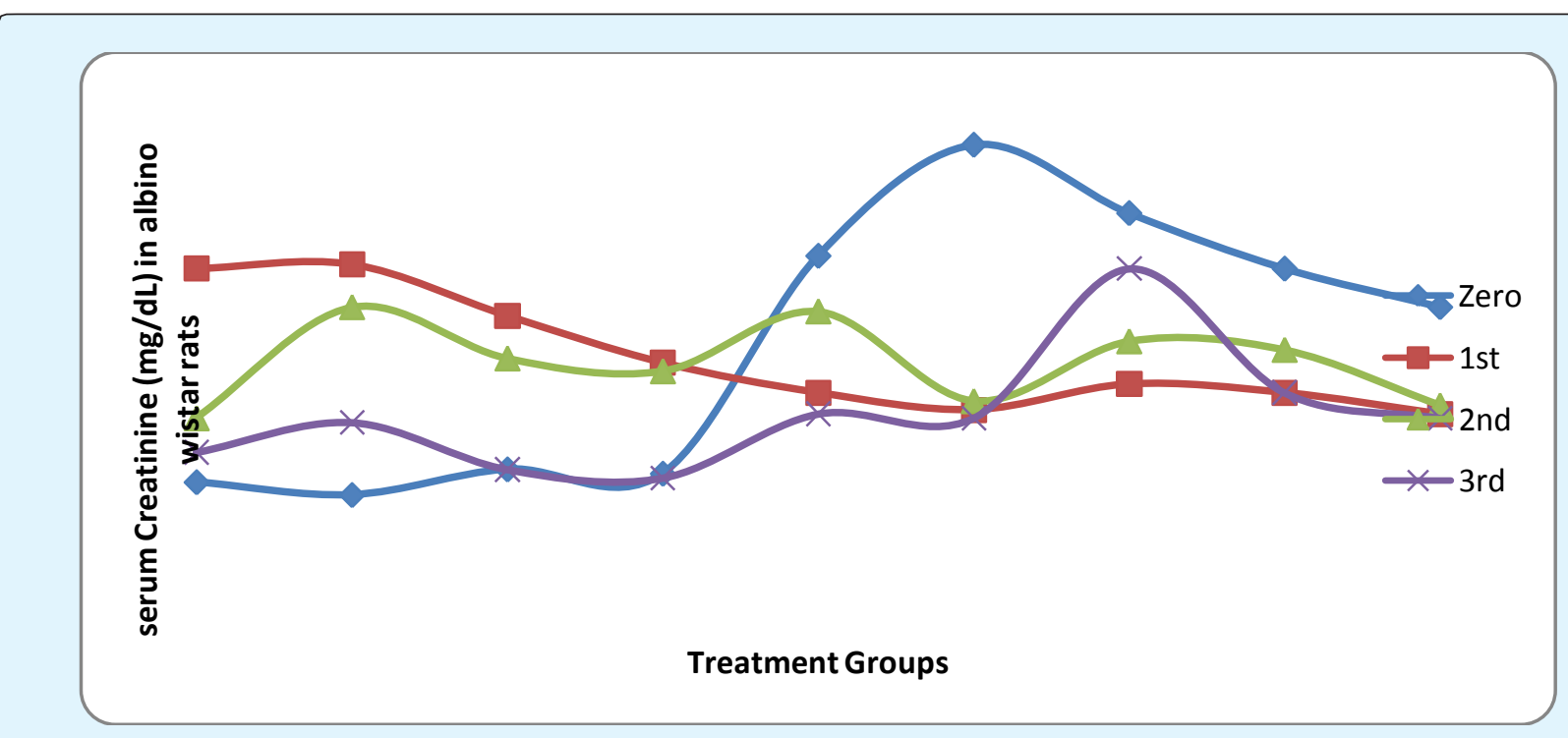

Figure 2: The effects of different doses of lithium carbonate alone or with L- ascorbic acid on serum creatinine. 


\section{International Journal of Biochemistry \& Physiology}

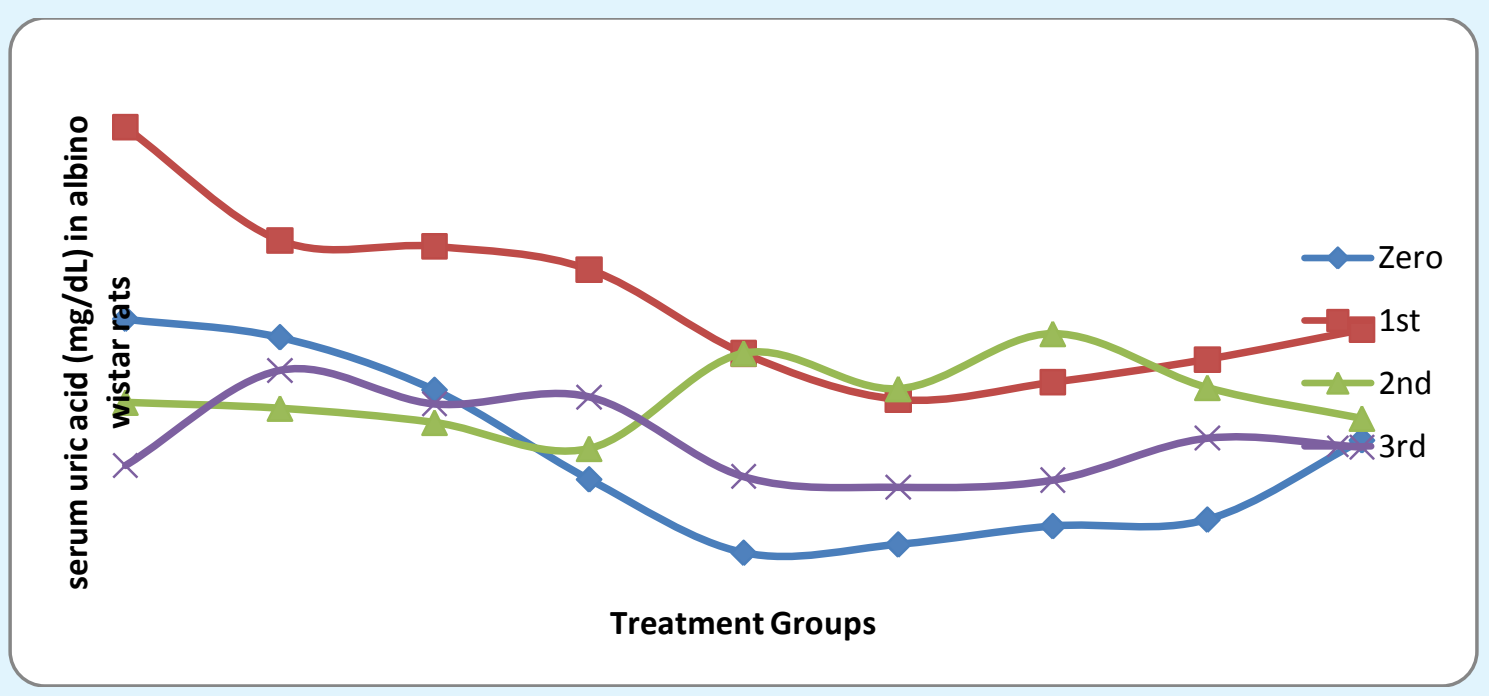

Figure 3: The effects of different doses of lithium carbonate alone or with L- ascorbic acid on serum uric acid.
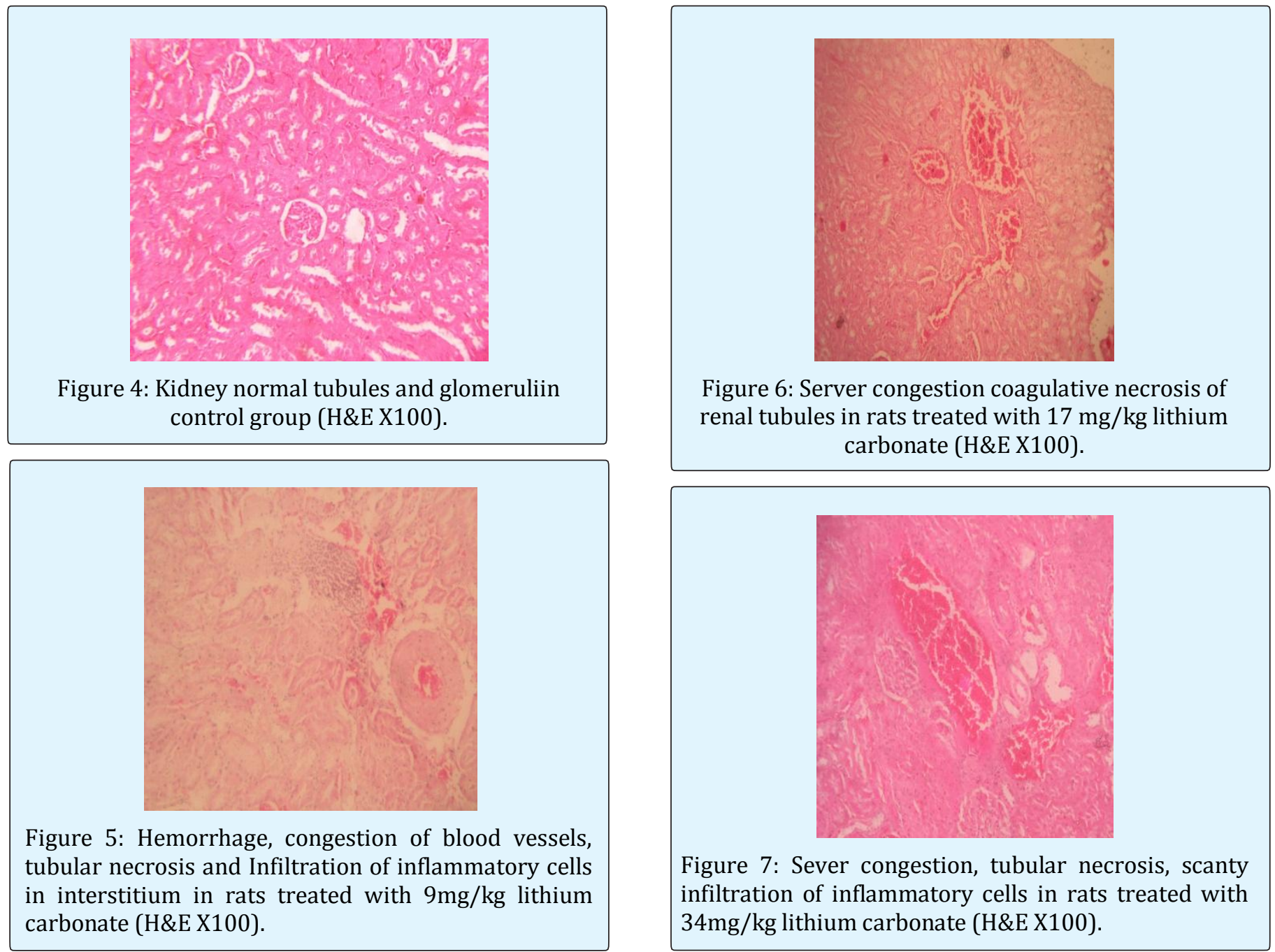

Figure 7: Sever congestion, tubular necrosis, scanty infiltration of inflammatory cells in rats treated with $34 \mathrm{mg} / \mathrm{kg}$ lithium carbonate (H\&E X100). 


\section{International Journal of Biochemistry \& Physiology}
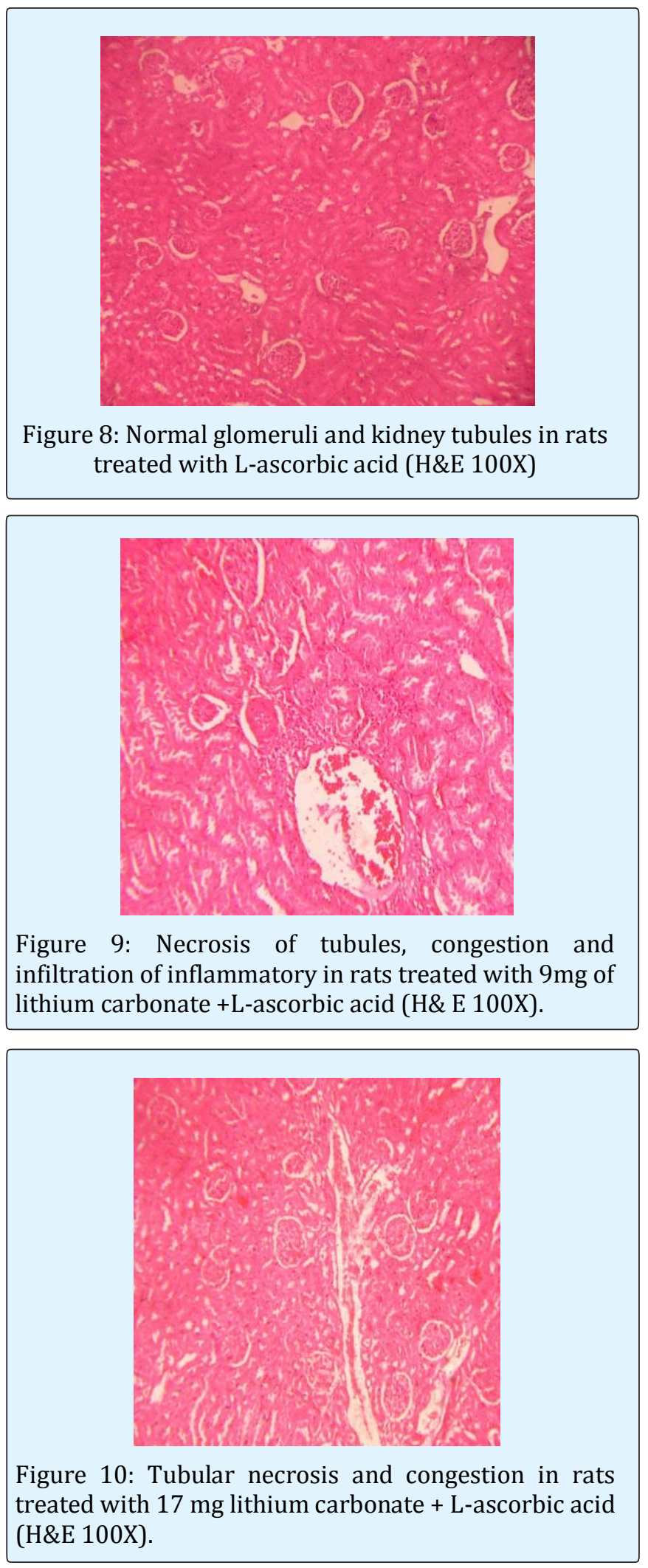

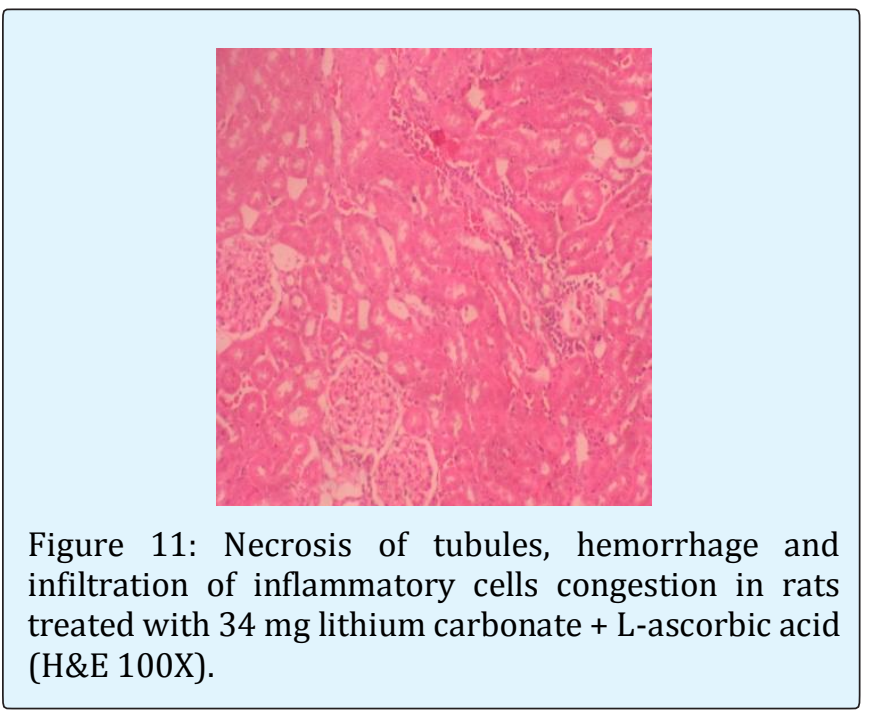

\section{Discussion}

Since lithium carbonate is highly effective in controlling and preventing recurring of manic depressive episodes, its use in psychiatry to rehabilitate patients continues despite its complications [17]. Structural and functional effects of lithium carbonate have been studied by various workers from time to time [18]. Chronic lithium intoxication is more common. There is gradual accumulation of lithium, usually due to decreased excretion. Lithium poisoning causes impaired renal function, drug interactions, volume depletion, and concurrent illnesses such as congestive, inflammation and necrosis [18]. Lithium exerts its effects on a wide range of cellular functions by inhibiting inositol production, affects the protein kinase $\mathrm{C}$ signaling pathway, and inhibits glycogen synthase kinase [19]. Early recognition and management of lithium induced organ toxicity can save lives and reduce significant morbidity.

In the current study the total mean of serum urea in different doses of lithium carbonate showed a highly significant increase $(\mathrm{P}=0.000)$ compared to the control group. This result agreed with Devesh KJ, et al. [20] who found that the concentration of serum urea was significantly increased by oral administration of lithium treatment in rats. Also this result agreed with Aziz J, et al. who reported that therapeutic doses of lithium carbonate induce nephrotoxicity reflected as increase in serum urea [21]. A similar study done by Sharma S, et al. reported that lithium therapy treatment in rats caused increased urea [2]. The results also agree Kielczykowska M, et al. 


\section{International Journal of Biochemistry \& Physiology}

reported that lithium carbonate treated rats in the form of water solution by stomach tube for 6 weeks caused the increased serum urea [22]. A similar study conducted by Omar HE, et al. reported that different doses of lithium carbonate treated rats showed increase in all groups treated. Kidney damage was evident in the present study by histopathological findings [23]. Increasing of concentration in the serum urea provided information from cellular damage of kidney. In fact, urea is the first acute renal marker which increases when the kidney suffers any kind of injury [24].

In the present study the total mean of serum urea in different doses of lithium carbonate and L-ascorbic acid showed higher values compared to the control group. The results agreed with Kielczykowska M, et al. reported that lithium carbonate and L-ascorbic acid co administration treated rats in the form of water solution by stomach tube for 6 weeks caused the increased serum urea [22]. A similar study done by Omar HE, et al. who reported that different doses of lithium carbonate and antioxidants vitamin treated rats showed increase of urea levels in all treated groups [23]. A similar study done by Omar HE, et al. reported that different doses of lithium carbonate and other antioxidants as co administration the treated rats showed increase in urea in all treated groups [23]. This finding showed that urea levels may increase in animals treated with lithium carbonate, even when antioxidants were used.

In the current study the total mean of serum creatinine in different doses of lithium carbonate showed a significant $(p=0.000)$ increase compared to the control group except group D that was not changed. Omar HE, et al. reported that different doses of lithium carbonate treated rats showed increase of serum creatinine in all groups of the study, their results agreed with groups B and C but disagreed with group D [23]. Kielczykowska M, et al. reported that lithium carbonate treated rats in the form of water solution by stomach tube for 6 weeks caused no change in the concentration of the serum creatinine, their results agreed with group $\mathrm{D}$ and disagree with group C and B [22]. Also Omar HE, et al. reported that the concentration of serum creatinine was significantly increased in oral administration of different doses of lithium treatment in rats [23]. The increase of serum creatinine, can be attributed to the fact that, the increment of creatinine in blood could be related to the reabsorption of creatinine in the glomerular filtrate, lower rates of glomerular filtration, which might be expected due to perturbation of the renin-angiotensin system. This could cause reduction of renal cortical blood flow [25]. Which was evident in the present study by histopathological findings of the renal damage. On the other hand, increasing concentration of creatinine in the serum provide information from cellular damage of kidney. Sine creatinine is a known marker of renal functioning and its concentration in the serum increases as renal function decreases. The elevated creatinine levels observed in serum of lithium treated rats may be the reflection of reduced glomerular filtration capacity as reported by Joshi D, et al. [24].

In the present study the total mean of serum creatinine in different doses of lithium carbonate and L-ascorbic acid showed slight increase in group $\mathrm{C}$ and slight decrease in groups $\mathrm{D}$ and $\mathrm{E}$ compared to the control group. A similar study conducted by Omar $\mathrm{HE}$, et al. reported that, different doses of lithium carbonate and L-ascorbic acid treated rats showed unchanged level of serum creatinine in all groups treated, this study agreed with their results with exception of groups D and E [23]. The results also agree with Kielczykowska $M$, et al. who reported that lithium carbonate and L-ascorbic acid in co administration, in treated rats, in the form of water solution by stomach tube for 6 weeks caused slight increase in serum creatinine this agreed with group C in this study but different than groups (D and E) [22]. Tripathi S, et al. explained this to be attributed to the fact that, the increment of creatinine in blood could be related to the reabsorption of creatinine in the glomerular filtrate, lower rates of glomerular filtration, which might be expected due to perturbation of the renin-angiotensin system [25]. This could cause reduction of renal cortical blood flow; which was evident in the present study by histopathological findings of the kidneyes. This finding suggests the L-ascorbic acid may acted as protective element.

In the current study the total mean of serum uric acid in different doses of lithium carbonate showed a highly significant $(\mathrm{p}=0.000)$ decrease compared to the control group. Lithium carbonate well known antimanic agent, was found to decrease serum uric acid levels and produce uricosuric effect as reported by Anumonye A, et al., ElMallakh R, et al. [26,27]. Increased urinary excretion and decreased serum uric acid is one of the complications of lithium therapy, and has been observed in both experimental animal and human after lithium administration [26-28].

In the present study the total mean of serum uric acid in the groups treated with different doses of lithium carbonate and L-ascorbic acid showed no effect due to 


\section{International Journal of Biochemistry \& Physiology}

treatment, but the total mean of serum uric acid was significantly increased in the group received the high dose compared to group B, which received only ascorbic acid. The results agreed with Omar HE, et al. reported that, antioxidant beside lithium therapy increased the blood uric acid [23]. A similar study conducted by Kielczykowska M, et al. showed that, lithium carbonate and co administration treated rats in the form of water solution by stomach tube for 6 weeks caused changes in serum uric acid [22]. This suggested that, the increase of uric acid in blood could be related to the lower rates of glomerular filtration, which might be expected due to perturbation of the renin-angiotensin system. As it could cause reduction of renal cortical blood flow as stated by Tripathi S, et al. [25]. This was evident in the present study by the histopathological findings of the kidneys.

The findings of this study reflected tubular necrosis, congestion and infiltration of inflammatory cells as common pathological lesions observed in the kidney at different doses of lithium carbonate in the first experiment. This finding was supported by Loghin F, et al. who reported that chronic lithium treatment can produce significant inflammatory and congestive changes in kidney [4]. A similar study conducted by Mohammed A, et al. reported that the histopathological observations of the kidney tissue revealed many deformities and histological alteration due to lithium treatment [29]. The development of necrosis in proximal tubules, glomerular shrinking, tubular necrosis and loss of cellular integrity due to lithium exposure has been observed earlier also during lithium therapy [30]. The results of the present study were consistent with the previous findings of Lepkifker E, et al. in which renal insufficiency in long term treatment with lithium carbonate has been reported [31]. Similar study performed by Omar HE, et al. reported that the morphological examination of kidney revealed the finding that cellular architecture was disturbed following lithium treatment [23]. Several histopathological examinations revealed congestive or degenerative lesions, large areas of lesions and accumulations of leukocytes, glomerulosclerosis, peritubular infiltration with lymphocytes and mononuclear cells in the kidney of lithium treated rats and co-treatment with antioxidant improved those changes [32]. The study agreed with Sharma S, et al., as they reported congestive changes in kidney during long term of lithium therapy treatment in human and rats respectively [2]. The morphological examination of kidney revealed that cellular architecture was disturbed following lithium treatment. These findings are concomitant with the findings of Weiner D, et al. [33]. The present study agreed with Aziz J who reported that therapeutic doses of lithium carbonate induced nephrotoxicity in the form of necrosis of the renal tubules, alteration of cellular structures, degeneration, and glomerulosclerosis with congestion were observed [21]. The study agreed also with Kanfer A, et al. [34] and was supported by the finding of, Sharma $\mathrm{S}$, et al. as they detected chronic tubule-interstitial nephropathy after long term of lithium therapy treatment in human and rats respectively [2]. The pathogenies mechanism by which lithium causes alteration in kidney are not well understood and also lithium therapy induced renal damage [35]. Lithium plays a role as a modulator of pathway for inositol monophosphate, which results in decreased inositol concentrations and inhibition of cell cycle ,Thus, accumulation of lithium in cells of distal nephron can cause Tubular damage revealed that the modulation of the phosphoinositol pathway may play a role in kidney pathological changes after lithium treatment $[35,10]$.

In the current study the protective effect of L-ascorbic acid on kidney tubules was compatible with lithium carbonate doses. L-ascorbic acid reduce infiltration of inflammatory cells seen when lithium carbonate was applied alone. Antioxidant supplements may include a number of different free radical-fighting compounds. It is thought that antioxidants, such as vitamin $\mathrm{C}$ may reduce the damage caused by free radical in the bodies by inhibiting their formation [12]. This finding supported by Frei B, et al. who showed that histopathological examination revealed congestive or degenerative lesion, large areas of lesions and accumulations of leukocytes, glomerulosclerosis, peritubular of infiltration with lymphocytes and mononuclear cells in the kidney of lithium treated rats and co-treatment with antioxidant improved those changes [12]. The present study also revealed that the L-ascorbic acid may protect against lithium toxicity in kidney cells.

\section{Conclusions}

In conclusion, the present results suggested that lithium carbonate induced renal toxicity in rats at physiological and histopathological levels. It has also potentials of inducing adverse effects in rat blood values although, the precise mechanism of lithium carbonate toxicity still remains incompletely understood, the clinical use of lithium needs a carful and caution attention. And also, the data from the present study showed that Lascorbic acid alone or it's the interaction with lithium carbonate is effective in protection against lithium renal toxicity in rats. Lithium carbonate exposure caused a 


\section{International Journal of Biochemistry \& Physiology}

histological and biochemical changes and lithium accumulation but co-treatment with L-ascorbic acid showed clear protect on against lithium toxicity.

\section{References}

1. Groleau G (1994) Lithium toxicity. Emerg Med Clin N Am 12(2): 511-531.

2. Sharma S, Igbal M (2005) Lithium induced toxicity in rats; a hematological, biochemical and histopathological study. Bio Pharm Bull 28(5): 834844.

3. Dehpour AR, Emamian ES, Ahmadi-Abhari SA, Azizabadi-Farahani M (1998) The lithium ratio and the incidence of side effects. Progr Nueropsychopharmacol Biol Psychiat 22(6): 959-970.

4. Loghin F, Olinic A, Papa D, Socaciu C, Levcuta S (1999) Effect of long term administration of lithium and hydrochlorothiazide in rats. Met Based Drugs 6(2): 87-93.

5. Bourgeois JA (1991) Ocular side effects of lithium-a review. J Am Opt Assoc 62(7): 548-551.

6. Davies NL (1991) Lithium toxicity in two dogs. J Soc Afr Vet Assoc 62(3): 140-142.

7. Hensen J, Haenelt M, Gross P (1996) Lithium induced polyuria and renal vasopressin receptor density. Nephrol Dial Trans 11(4): 622-627.

8. Goodman L, Gillman AG (1996) Thyroid and antithyroid drugs. In: The pharmacological basis of therapeutic. 9th (Edn.), McGraw Health Professions Division, New York, pp: 446-449.

9. Clarke WB, Clarke RM, Olson EK, Barr RD, Downing RG (1998) Binding of lithium and boron to human plasma protein. Biol Trace Elem Res 65(3): 237-249.

10. Tamm VK, Green J, Schwieger J, Cohen AH (1996) Nephrotic syndrome and renal insufficiency associated with lithium therapy. Am J Kidney Dis 27(5): 715-720.

11. Klemfuss H, Bauer TT, Green KE, Kripke DF (1992) Dietary calcium blacks lithium toxicity in hamsters without affecting circadian rhythms. Biol Psychiat 31: 315-321.
12. Frei B, England L, Ames B (1989) Ascorbate in an outstanding antioxidant in human blood plasma. Proc Natl Acad Sci USA 86: 6377-6381.

13. Sharif N, Rabia A, Iftihar 0 (2011) Adverse effects of withdrawal of chronic lithium therapy on liver, a histopathological study. Pakistan J Zool 43(6): 11551180.

14. Toghiani T, Gholami M, Zendedel A, Assadollahi V (2012) The effects of low-dose lithium carbonate on the spermatogenic parameters in the adult male wistar rats. Life Sci J 9(4): 4360-4367.

15. Turner RD, Bancroft JD, Stevens A (1996) Theory and Practice of Histological Techniques. $4^{\text {th }}$ (Edn.), Churchill Livingstone, Hong Kong, pp: 35-112.

16. Snedecor GW, Cochran WC (1989) Statistical Methods. $8^{\text {th }}$ (Edn.), Iowa State University Press: Ames, Iowa.

17. Csutora P, Karsai A, Nagy T, Vas B, Kovács LG, et al. (2005) Lithium induces phosphoglucomatase activity in various tissues of rots and in biopolar patients. Int J Neuro Psychpharmacol 9(5): 613-619.

18. Yip K, Yenng WT (2007) Lithium overdose causing non-convulsive status epileptics-the importance of lithium levels and the electroencephalography in diagnosis. Hongkong Med J 13(6): 471-474.

19. Pilcher $H$ (2003) Drug research: the ups and downs of lithium. Nature 425(6954): 118-120.

20. Devesh KJ, Dusayant SC, Anumesh KP (2013) Lithium potentiate oxidative burden and reduced antioxidant status in different rat organs system. I J Toxicol Pharmocol Research 5(1): 9-14.

21. Aziz J (2015) The structural and functional changes induced by lithium of the renal cortex of growing albino rats; ultra structural and laboratory study. Acta Medica Int 2 (1): 70-78.

22. Kielczykowska M, Kocot J, Kurzep J, Lewandowska A, Musik I, et al. (2014) Could Selenium Administration Alleviate the Disturbances of Blood Parameters Caused by Lithium Administration in Rats?. Biol Trace Elem Res 158(3): 359-364. 


\section{International Journal of Biochemistry \& Physiology}

23. Omar HE, Ibrahim AT, Magdy MA, Ahmed AE (2016) The protective effects of zinc and vitamin $\mathrm{E}$ supplementation against kidney toxicity by lithium in rats. EJBR 6(1): 21-27.

24. Joshi D, Chauhan D, Pathak K (2013) Potentiate burden and reduced antioxidant status in different rat organs system. Int J ToxicalPharmcol Res 5(1): 9-14.

25. Tripathi S, Somashekur B, Mahdi A, Gupta A, Mahdi F, et al. (2008) Aluminum mediated metabolic changes in rats serum and urine: Aproton magnetic resonance study. J Bio Mol Toxiol 22(2): 119-127.

26. Anumonye A, Readig H, Knight F, Ashcroft GW (1968) Uric-acid metabolism in manic-depressive illness and during lithium therapy. Lancet 1(7555): 1290-1293.

27. El-Mallakh R, Jefferson J (1999) Prethymoleptic use of lithium. The American Journal of Psychiatry 156(1): 129.

28. Martinez M, Stavroulak T, Tsaparas N, Suki WN, Eknoyan G (1975) Renal effects of lithium administration in rats: alterations in water and electrolyte metabolism and the response to vasopressin and cyclic-adenosine monophosphate during prolonged administration. J Lab Clin Med 86(3): 445-461.

29. Mohammed A, Yasser E, Muhammad F, Muhammad W (2011) Lithium Induced Toxicity in Rats: Blood Serum Chemistry, Antioxidative Enzymes in Red
Blood Cells and Histopathological Studies. Biol Pharm Bull 34(2): 272-277.

30. Markowitz G, Radhakrisnan J, Kambham N, Valeric A, Hines W, et al. (2000) Lithium nephrotoxicity: a progressive combined glomerular and tubulointerstitial nephropathy. J Am Soci Nephrol 11(8): 1439-1449.

31. Lepkifker E, Sverdlik A, Lancu I, Ziv R, Segev S, et al. (2004) Renal insufficiency in long-term lithium treatment. Clin Psychiatry 65(6): 850-856.

32. Weiner D, Leader JP, Bedford JJ, Verlander JW, Ellis G, et al. (2014) Effects of chronic lithium administration on renal acid excretion in human and rats. Physiol Rep 2(12): e12242.

33. Swann A, Koslow S, Katz M, Maas J, Javaid J, et al. (1987) Lithium carbonate treatment of mania. Cerebrospinal fluid and urinary mono amine metabolites and treatment outcome. Arch Gen Psychiatry 44(4): 345-354.

34. Kanfer A, Blondiaux I (2000) Renal and metabolic complications of lithium. Nephrologie 21(2): 65-70.

35. Grunfled JP, Rossier BC (2009) Lithium nephrotoxicity revisited. Nat Rev Nephrol 5(5): 270276. 